\title{
Utility and Rights: Two Justifications for State Action Increasing Equality
}

\author{
C. Edwin Baker $†$
}

In recent years numerous proposals ${ }^{1}$ have been advanced, some from surprising sources, ${ }^{2}$ that would move American society toward greater economic equality. Although specific bills designed to guarantee a minimum income have so far failed to pass, practical interest in such legislation and in protecting citizens against specific deprivations is probably higher than in any other period. Still, reform efforts have rarely drawn upon established philosophical tradition to support their efforts.

This article begins to draw those connections. It will develop and compare theoretical justifications for state interventions in the market which would guarantee to every member of society either a minimum income or minimum satisfaction of "just wants."3 Specifically, it focuses on two justifications-one derived from traditional utilitarian theory, ${ }^{4}$ the other from a theory of rights put forward most recently and most persuasively by Ronald Dworkin. ${ }^{5}$ The utilitarian-based ap-

$\dagger$ Assistant Professor of Law, University of Toledo; Fellow in Law \& Humanities, Harvard University.

1. 26 Cong. Q. Almanac 1030-41 (1970); 25 id. 833-40 (1969).

2. R. Nixon, Welfare Reform-A Message from the President, H.R. Doc. No. 146, 9lst Cong., lst Sess. (1969) (proposed Family Assistance Plan), reprinted in 115 Conc. REC. 23143, 23251 (1969).

3. I employ the term "just wants" in the same sense as used in Michelman, Foreword: On Protecting the Poor Through the Fourteenth Amendment, 83 Harv. L. REv. 7, $13-14$ (1969). Different terms have been used to refer to much the same notion. Musgrave uses the term "merit wants." R. Muscrave, The Theory of Public Finance 13-14 (1959). Calabresi uses the term "merit goods." Calabresi \& Melamed, Property Rules, Liability Rules, and Inalienability: One View of the Cathedral, 85 HARv. L. Rev. 1089, 1100 (1972). James Tobin describes the phenomenon as one of "specific egalitarianism," as opposed to "general egalitarianism." See Tobin, On Limiting the Domain of Inequality, 13 T. LAW \& ECON. 263 (1970).

4. See J. Bentham, An Introduction to the Principles of Morals and Legislation (W. Harrison ed. 1948). Simply viewed, utilitarianism can be described as the theory that the single criterion by which acts or policies ought to be judged is their contribution to the greatest happiness of the greatest number.

5. Dworkin relies heavily on a philosophical tradition growing out of Kant's ethical writings, which is enriched by use of Wittgenstein's investigations. Dworkin's approach to rights was presented in lectures at Yale in the fall of 1970. These lectures and his article, Taking Rights Seriously, in Is L.Aw DEAD? 168 (E. Rostow ed. 1971) [hereinafter cited as Dworkin], are the main sources for the second approach considered in this paper.

Dworkin's analysis of rights and the requirements for state guarantees which follow from it can be viewed as a justification for Michelman's "minimum protection" ap- 
proach will develop the thesis that total societal utility is systematically maximized by a distribution of wealth where equality is greater than it would be if the total wealth of the society, ${ }^{6}$ not utility, were maximized. ${ }^{7}$ The second approach, based on Dworkin, will develop an argument for limiting total utility in order to guarantee certain "rights" (or the claims to have just wants satisfied) to every member of society. Both approaches justify limiting total wealth in a way which increases equality.

Utilitarianism has long provided the most widely accepted philosophical rationale for policy decisions affecting the allocation of resources. It is frequently believed that utilitarian principles forbid any interference with the distribution created by a free market. ${ }^{8}$ The question explored in this section is why under utilitarian principles a group of people should choose an economic solution which provides for the satisfaction of the basic needs of everyone, or which guarantees a certain income to each person, even though it has the effect of

proach. While Michelman's work is not primarily an attempt to justify "minimum protection," he does suggest using a Rawlsian justification, see Michelman, supra note 3, at 14-15, 35. Rawls might conclude that "minimum protection" would be the result of applying his two principles of justice at the constitutional or legislative stage; Michelman has given a possible basis for concluding that a Rawlsian legislator would favor fulfilling "just wants." But cf. J. RAwLs, A Theory of Justice 275, 277 (1971), where Rawls suggests that one way to correct for some groups being poor may be to use graded income supplements (a so-called negative income tax). Michelman's argument at many points requires a justification for satisfying "just wants" even at the cost of "nonefficient" or non-Pareto optimal intervention; he fails to offer such a convincing justification. See Michelman, supra note 3 , at 30 .

6 . In this article wealth is defined as the product of a quantity of goods times their price, $W=Q P$. Assuming constant prices, wealth increases when the quantity of valued goods increases.

7. The policy of increasing equality is generally viewed as contrary to the teachings of utilitarian economics because of the negative effects of market intervention on production. Ralph Winter implicitly relies on this view when he concludes that a "good case can be made... that the goals of equalizing income and reducing poverty are simply inconsistent." Winter, The Equal Protection Clause, 1972, Sup. CT. REv. 41, 80. The notion that interference with the market except to correct for a market failure will cause a "misallocation" and a decrease in total satisfaction or total societal welfare is explicitly adhered to by other legal commentators. See, e.g., Bork, Resale Price Maintenance and Consumer Welfare, 77 YALE L.J. 950, 954-55 (1968): "If [resale price maintenance] creates efficiency and so increases society's wealth, there is no more reason for a legislature to classify it as an undesirable practice ... than there is to classify the more efficient rearrangement of machinery as a thing wrong in itself simply because it produces income." See also Coase, The Problem of Social Cost, 3 J. LAw \& ECON. 1 (1960). Coase demonstrates that in a "perfect" market situation, an economically efficient or Pareto optimal result will occur no matter what the original distribution or entitlements are. The conclusion would seem to follow that any market intervention other than to correct for "market failures" of certain types would lead to nonoptimal results and thus cause "misallocation."

8. Winter, supra note 7 , at 62 . 
lowering the total production of valued goods. ${ }^{9}$ Or, to give a limited numerical example, why might a group rationally choose solution $\mathbf{B}$ rather than solution $\mathrm{A}^{10}$ in Table I?

\section{Table I}

Persons

$\begin{array}{lrrr} & \text { A } & \text { B } & \text { C } \\ X & 10 & 8 & 4 \\ \mathrm{Y} & 9 & 6 & 4 \\ \mathrm{Z} & 1 & 2 & 4 \\ \text { Total } & 20 & 16 & 12 \\ \text { (the numbers represent quantities of valued goods) }\end{array}$

In answering this question we must first enter the utilitarian framework, making a number of assumptions which may be contrary to reality but which are frequently made by utilitarian economists. ${ }^{11}$ First, it is assumed that there is an inverse relation between total wealth and equality, as a result of the existence of a dynamic system or transaction costs. ${ }^{12}$ In other words, the distribution system and the

9. The total production of valued goods will be called "wealth" and will be distinguished from utility. I will assume constant prices; wealth will be increased when $Q_{2} P \geq Q_{1} P$, where $Q_{1}$ represents the total goods before the change, $Q_{2}$ represents goods after the change, and $P$ equals price. Realistically, a large change in $Q$ will cause a change in $P$. However, for the purposes of this argument $I$ will ignore this effect. Societal utility will be assumed to be equal to the sum of individual utilities and to be affected by changes in the distribution of wealth and by changes in total wealth.

10. The A-type solution represents a distribution where there is no state intervention and where wealth is maximized.

11. See notes $15,17,18$ infra.

12. The term "dynamic" means that what is done now has an effect on what is done later; e.g., removing incentives may affect people's willingness to work, and thus affect how much is produced. Bentham and Abba Lerner argue that if it were not for the dynamic or time factor, it could maximize societal utilities to have complete equality. J. Bentham, The Theory of Legislation 133-41 (1914); A. Lerner, The Economics of Control 23.40 (1944). Transaction costs are relevant because if resources are used in the process of increasing equality (collecting taxes and operating a welfare system both cost money), then increasing equality would result in a decreased total of individual wealth (sum of economic goods), since the efforts and resources used in the process do not result in the production of "economic goods" which anyone could possess or use. The only author of whom I am aware who rejects the Lerner argument for the static case is R. POSNER, ECONOMIC ANALYsis of the LAw 216-18 (1972). He claims that there is "no theoretical basis" for concluding "that a transfer of money from a wealthy man to a poor one is likely to increase the sum of the two men's total utilities." Id. at 216. Granted, without knowing people's utility curves and being able to compare them, the theoretical conclusion can only be that 
production system are interrelated, so that interference with one affects the other. ${ }^{13}$ An unequal distribution will result in the greatest production of valued goods, because wealth and equality are related inversely. ${ }^{14}$ Such a claim is often made by supporters of a free market

an increase of utility from increasing equality is "likely" (rejected by Posner) or would increase "probable total satisfaction" (Lerner). This conclusion, however, does follow unless it is assumed that utility curves of the rich are higher than those of the poor and would remain so even as the poor became better off. See A. LERNER, supra, at 35-36.

As Lerner points out, if the "experience of higher income had the effect of raising the curve of marginal utility of income," this fact would only relate to how fast the transition to greater equality should occur. Id. at 35. Thus, in order to say that the distribution should be unequal because the rich have higher utility curves, one must say that those who become rich are inherently better able to derive utility from money, a belief Lerner labels racist, id. at 35. At a minimum, it has little basis in reason or observation.

13. Neoclassical economists and legal commentators generally accept the inverse relation between state nonmarket promotion of equality and societal production of wealth. See notes 6, 7 supra. However, from some perspectives this inverse relation may not be true or relevant. For example, from a Marxist perspective, 1) the bourgeois definition of wealth used in this article would be rejected; 2) a goal of maximum production of bourgeois wealth would be questioned; 3) the emphasis on equality of distribution rather than on forms of production would be criticized. Marx explains: "The wealth of those societies in which the capitalist mode of production prevails, presents itself as an immense accumulation of commodities." $1 \mathrm{~K}$. MARX, CAPITAL 35 (F. Engels ed. 1967). "For real wealth is the developed productive force of all individuals. It is no longer the labour time but the disposable time which is the measure of wealth." K. MARx, THE GRUNDrisse 145 (D. McLellan ed. 1971) [hereinafter cited as Grundrisse]. The "highest development of productive forces" corresponds to the "richest development of the individual." Id. at 120. Marx argues that the whole evaluation process of bourgeois economics fails to make sense, because bourgeois economics takes man and his wants and orientations for granted while Marx argues that man is central to any notion of wealth; that wealth increases as man develops. "To economize on labour time means to increase the amount of free time, i.e., time for the complete development of the individual, which again reacts as the greatest productive force on the productive force of labour .... Free time ... transforms anyone who enjoys it into a different person, and it is this different person who enters the direct process of production." Id. at 148 .

Marx rejects the commodity notion of wealth; he argues as well that emphasis on equalizing distribution should not be a primary goal, but rather that emphasis must be on the mode of production out of which come differing organizations of distribution. "An enforced raising of wages ... would therefore be nothing but a better slave-salary and would not achieve either for the worker or for labor human significance and dignity." Economic and Philosophic Manuscripts 1844: WRitings of the Young Marx on Philosophy AND Society 298 (L. Easton \& K. Guddat eds. 1967) (emphasis added). "A definite form of production thus determines the forms of consumption, distribution, exchange and also the mutual relations between these various elements." GRUNDRIsse, supra, at 33. See also id. at 152; K. MARx, Critique of the Gotha Program 3 (C. Dutt ed. 1938). In this article, I will not adopt this Marxist perspective but will limit myself to exploring the implications of the presently dominant form of economic analysis, derived from utilitarianism.

14. Traditional theory says that an optimal production of valued goods (including leisure) occurs when there is no market interference except to correct for market imperfections. If one assumes this to be the case, wealth and equality would be directly related when the intervention is to decrease the amount of equality resulting from market transactions and inversely related when the intervention is to increase equality. Also, most would agree that the negative effect of intervention would increase as the amount of intervention increased (at least up to some point). Since the only concern here is with the part of the trade-off curve from the point of maximum production and no intervention to the point of lesser production and intervention to increase equality, we can conclude 1) that wealth production and equality will be 
system, ${ }^{15}$ and this assumption is accepted for the purposes of this article.

A second important assumption, which applies to the evaluation of individual utilities, is that a person derives utility only from his

inversely related over this range, and 2) that the trade-off function is a smooth curve, and that the slope of the trade-off curve at the point of no intervention is zero.

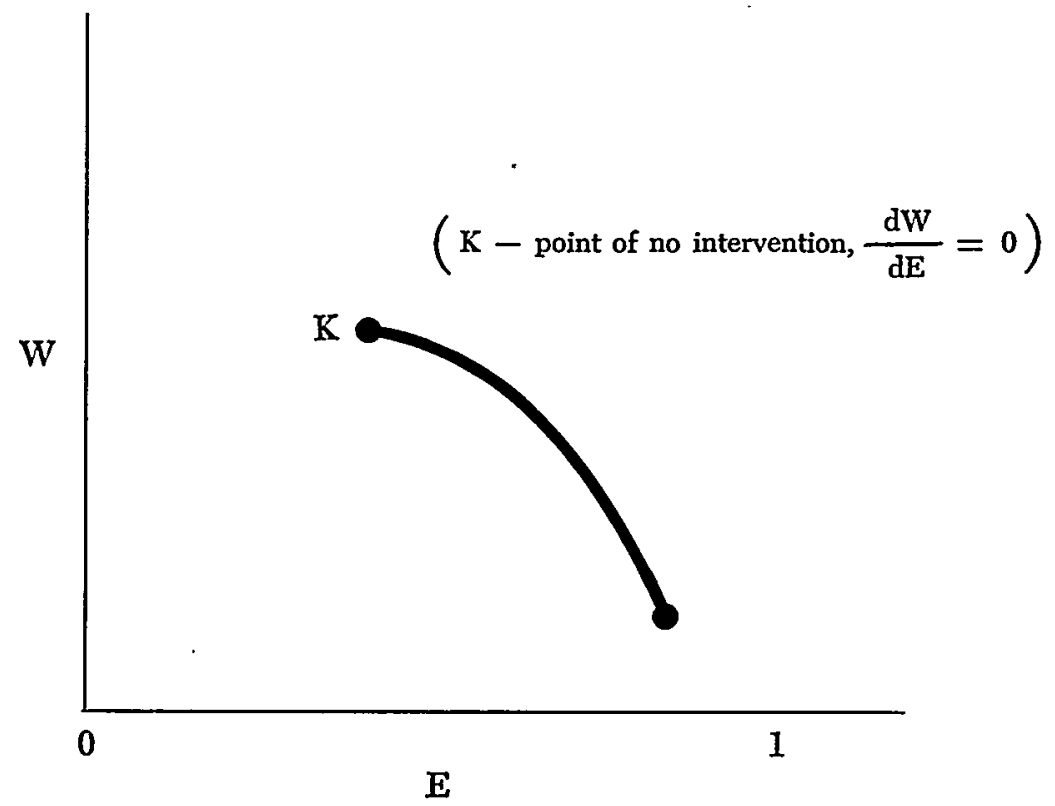

Even if some authoritarian intervention which decreased equality could be shown to increase production (only explained by traditional theory in terms of failing to value leisure and other "nonmarket" goods or of correcting market failures), there will always come a point where this increase in production could not occur. On the other hand, increases of income to the poor may in some circumstances amount to a relatively high. yield investment in a product factor. See $3 \mathrm{G}$. Myrdal, Asian Drama 1912-18 (1968).

15. Inequality, it is claimed, serves an important function because an incentive system is necessary to induce productive efforts, or, more generally, proper factor payments result in the most productive employment of resources, even though this results in inequality. Assuming an ideal market model, any intervention by the state would cause a "misallocation" of resources, and consequently a smaller production of valued goods. Only intervention to handle market failures (which were excluded from the ideal model) does not decrease total wealth. Unless people's utility functions are interdependent so that wealth distributions create a public goods problem or unless there is market failure, then, a state guarantee of a minimum level of individual income is the type of intervention which causes a "misallocation" or a non-Pareto optimum result. (A Pareto optimum exists when no trade or change could be made which would make someone better off without leaving someone else worse off. An efficiency or Pareto justification for a change may exist if the gainers could pay off the losers from their gains, even if the pay-off does not actually occur.) But cf. Calabresi, Transaction Costs, Resource Allocation and Liability Rules-A Comment, II J. LAw 8. ECON. 67 (1968). Calabresi argues that in certain situations the choice between intervention or nonintervention, or between different types of intervention, will not, given our knowledge, be determinable by reference to the concept of maximizing total wealth. In such situations one should choose the solution which maximizes other values which one might hold, e.g., equality. 
own wealth. In other words, his utility is independent of any other individual's happiness or well-being. "Goods" are assumed to have a value for a person only to the extent that the "goods" have a direct effect on him, and any effect on others is irrelevant or nonexistent. Thus, only the "utils"16 that a person receives from his portion of total wealth will be considered, not utils which may be derived from sources which relate to relations with other people. ${ }^{17}$

16. "Utils" are units of whatever is being maximized by utilitarian theory, generally happiness, pleasure (the opposite of pain), or satisfaction.

17. It might well be argued that interdependence is a more realistic assumption. Dropping the assumption of independence of utility functions would indeed be a more direct way to strengthen the argument for increasing equality. See, e.g., Hochman \& Rogers, Pareto Optimal Redistribution, 59 AM. Econ. REv. 542-57 (1969). The argument from interdependence is frequently misunderstood and creates measurement and conceptual difficulties. For example, while juggling the concepts of cost and value, Winter argues that the costs of an in-kind redistribution are always greater than the value received by the poor as the poor perceive it. Winter, supra note 7 , at 74 . Even assuming interdependence of utility functions, given declining marginal utility of wealth, this statement is no basis for saying that utility would not be increased by such distributions. When interdependence is assumed, the rich might benefit from providing the poor with certain specific goods; and, although they may not benefit enough to want to pay for the benefits, cf. id. at 77, the increased utility to the rich from the poor receiving these specific benefits plus an increased utility to the poor may be greater than the loss of utility to the rich due to the cost of providing the benefits plus the loss to the poor due to having the specific goods rather than money. Thus, contrary to Winter's conclusion, $i d$., assuming interdependence suggests a utility analysis conclusion that in-kind redistribution not only increases total satisfaction but does so to a greater degree than monetary redistribution. By assuming independence, this article derives utilitarian arguments for action which increases equality that may be on firmer ground than those based on interdependence. The plausibility of declining marginal utility is better established than the specific forms of interdependence needed by the HockmanRogers argument, supra.

It may be more significant at this stage to trace out the implications of the assumption of independence of utility functions. Most generally, the assumption allows value to be given only to relations between a person and an object or service and not to relations between people-it is subject-object, not subject-subject, oriented. See generally R. Wolff, The Poverty of Liberalism 162-99 (1968). This means: 1) States or conditions such as equality are not given a value; 2) the effect the production system has on the relationships between people is not given a value; 3 ) the effect that the distribution system has on the relationships between people is not given a value. The fundamental noncommodity nonobject nature of these values makes them unsuitable for market handling. These failures of the market lead to two different criticisms. First, to the extent that a market fails, when making allocations, to consider certain values, we have no reason to expect that it makes "efficient" or desirable allocations. The market fails as a value-free and as an efficient allocator of goods. Second, to the extent that the existence of the market affects interpersonal values, its existence may itself be a (negatively or positively valued) "good" which itself cannot be valued correctly by market processes. Tribe, in an excellent analysis of systematic distortions involved in the policy sciences, shows that "procedures that shape individual and social activity have significance independent of the final products they generate." Tribe, Policy Science: Analysis or Ideology?, 2 Pull. \& PuB. Affarrs 66-79 (1972). He argues that the "processes and rules that constitute the enterprise and define the roles of the participants matter quite apart from any identifiable 'end state' that is ultimately produced. Indeed, in many cases it is the process itself that matters most." Id. at 83 .

The assumption that utility functions are independent, if deeply believed, becomes a theory about the nature of man. It is perhaps at this level that the most cogent arguments are made against the assumption and its consequences. On the notion that market relations cause alienation between man and man, see EcoNoMIC AND PHILOSOPHIC MANUSCRIPTS (1844): WRItings of THE Young MARx, supra note 13, at 295.96, 307.08; H. MARcuse, Reason and Revolution 279 (1941). Although his evaluation may differ, Weber makes similar observations. He states: "Where the market is allowed to follow its own autonomous tendencies, its participants do not look toward the persons of 
If a utilitarian believed that each unit of wealth an individual received was of equal value to the individual-that is, had the same utility-he would have to conclude that only an A-type solution (referring to Table I) would be the utility-maximizing choice. However, it is more reasonable to adopt a third assumption: that people have a declining marginal utility for wealth. ${ }^{18}$ People place a higher value on their first dollar than their second, on their second dollar than on their third. A poor man would thus value an extra dollar more than would a rich man, while everyone would value the first dollars of his income more highly. Given this third assumption, a partial redistribution of income would maximize the total of individual utilities, even though (according to our first assumption) total societal wealth would be somewhat reduced as a result.

An example will clarify this conclusion. Theoretically, if we knew the typical individual utility function for wealth ${ }^{19}$ and the amount

each other but only toward the commodity." "[T] to any type of fraternal relationship." "The private enterprise system transforms into objects of "labor market transactions" even those personal and authoritarian-hierarchical relations which actually exist in the capitalistic enterprise." M. WEBER, ON LAw IN ECONOMY AND SOCIETY 190-93 (M. Rheinstein ed. I925). See Parsons, Introduction, in M. Weber, The Theory of Social and Economic Organizations 33 (T. Parsons ed. 1947). Full treatment of these arguments is beyond the scope of this article.

18. A declining marginal utility for wealth implies that for any given individual each additional unit of wealth increases utility by a decreasing magnitude; or that $\frac{d U}{d W}>0 ; \frac{d^{2} U}{d W^{2}}<0$.

19. I use "typical" to mean "average." Average might imply that each function is known and that an average of all functions can be obtained by addition and division. However, to know every individual function we prestumably would have to know with which individual it was connected. In order to maximize utility, society would have to distribute the total depending on whether a particular person had a sharply or slowly declining utility function. The problems with this include: the absence of reliable techniques for making interpersonal or cardinal intrapersonal comparisons; the costs of administering such a system, which would cause greater utility losses than the resulting utility gains; and the possible ethical complaints about making distributions on such a basis. Calculations based on an average or typical utility function lead to a suggested distribution which might not produce the highest possible total utility, but should lead to a higher total utility than can be expected from the use of any other basis of calculation. Deviations from any maximums will be statistically likely to be smaller than if any other function is used, assuming either that one does not know or finds unusable each individual's utility function. See A. LERNER, supra note 12 , at $28-32$.

The use of a "typical" utility function, which would be the basis for the claim made in the text that the poor person receives greater utility than the rich person from the extra dollar, might appear to involve an unjustified interpersonal comparison of utility. The problem of interpersonal comparisons of utility is a label used primarily to describe two separate issues: whether utility of different people is by nature comparable; whether specific comparisons can be made. To assume, as we do here, that a typical utility function can be used for different people and that the addition of the results gives accurate information about probable utility effects, involves only the assumption that the utility of different people is similar, in the sense that it is the same kind of thing, but that comparisons of individual differences in capacities to derive utility from wealth cannot (or will not) be made. The use of a typical utility function for different individuals and the addition of the results does not involve interpersonal comparisons in the second sense-and it is in the second sense that the validity of interpersonal comparisons is normally challenged. 
total wealth would change with an increase in equality, ${ }^{20}$ then we could determine the exact degree of equality which would maximize total societal utility. For illustrative purposes, I will use a two-person model, and will choose equations which are arbitrary ${ }^{21}$ except for the fact that they correspond to the two critical assumptions mentioned above, namely, that wealth and equality vary inversely, and that every individual has a diminishing marginal utility for wealth.

The equation $W=\frac{100}{4 \mathrm{E}^{2}+1}$ is consistent with the assumption that wealth and equality are inversely related. In addition it represents a smooth function of the relation between $E$ and $W$, such that the first increase of $\mathrm{E}$ results in the smallest corresponding change in $W .{ }^{22}$ ( $W=$ total wealth in the society; $E=$ equality, expressed in this twoperson model as $E=\frac{a+b-|a-b|}{a+b}$, or, if $a \geqslant b, E=\frac{2 b}{a+b}$, where "a" represents the wealth of $A$, and " $b$ " represents the wealth of $B$. $E$ varies from 1 when $A$ and $B$ have equal wealth, to 0 , when either $A$ or $B$ has all the wealth and the other has nothing.) $)^{23}$ Next, assume $u=\sqrt{w}$, where " $u$ " represents individual utility and " $w$ " represents individual wealth. This equation represents our rational assumption that individuals have a declining marginal utility for wealth. Total societal utility is the sum of individual utilities: $U=$ $\sqrt{a}+\sqrt{b}$, where $U$ represents total society utility. Utility (U) can now be expressed as a function of equality (E), and the amount of equality necessary to maximize total societal utility can be determined by simple calculus. ${ }^{24}$ Under the formula selected for this il-

20. The knowledge needed is how great a misallocation would result from an intervention to obtain a given increase in equality.

21. The equations are not intended to express actual conditions in the world, but the form of the curves represented fits the criteria of our assumptions. It can be shown algebraically that any equations satisfying the assumptions of diminishing marginal utility and an inverse relationship between total wealth and equality will yield the type of results produced in the text.

22. See note 14 supra \& note 25 infra.

23. Wealth is expected to be greatest when $\mathrm{E}=\mathrm{K}, \mathrm{K}$ being the level of equality produced by a perfect market. However, the equations reflect the correct shape of the functions if they represent the interval between no intervention and intervention which results in complete equality $(E=1)$. This is the only interval with which we are concerned. See note 14 supra.

24. The above equations can be used to show that $U=\frac{10(\sqrt{2-\mathrm{E}}+\sqrt{\mathrm{E}}) \text {. }}{\sqrt{8 \mathrm{E}^{2}+2}}$ By finding $\frac{d U}{d E}$, setting it equal to 0 , and evaluating the second derivative, it is easy to find the value of $E$ where $U$ is maximized. In this case, the maximum value of $U$ is 11.836 which is attained when $E=.146$. Substitution of this value for $E$ into the equation for wealth yields the result that $W=92.1435$, as contrasted with a value of $W$ equal to 100 when $E=0$. 
lustration, utility is maximized when $\mathrm{E}=.146, \mathrm{~W}=92.1435$, and $\mathrm{U}=11.836$. According to the categories in Table $\mathrm{I}$, this is a B-type solution, because utility is maximized under conditions of less than maximum wealth and less than maximum equality. It should be noted, moreover, that implementing a B-type solution means, in effect, establishing a minimum income. Given the assumptions of an inverse relationship between equality and wealth and a declining marginal utility of wealth, maximizing utility will always produce a B-type solution, regardless of the exact mathematical formulation of the functional relationship between equality, wealth, and utility. ${ }^{25}$ Conse-

25. Equations relating wealth, utility, and equality can be written which fulfill the following conditions: 1) declining marginal utility of wealth; 2) decreases in wealth resulting from interventions. These equations show utility: a) maximized when $\mathbf{E}=\mathbf{K}$ [ $\mathrm{K}$ is the value of $\mathrm{E}$ when there are no interventions and $W$ is maximized]; $\mathrm{b}$ ) maximized when $\mathrm{E}=1$ [E $=1$ when there is perfect equality]; c) remaining constant when $\mathrm{l} \geq \mathrm{E} \geq \mathrm{K}$; d) maximized when $\mathrm{l} \geq \mathrm{E}>\mathrm{K}$. From these two conditions alone, intervention could increase, decrease, or not affect utility. If utility is maximized when $I \geq E>K$ then some redistribution would be justified if society were trying to maximize the sum of individual utilities-e.g., utility would be maximized when $\mathbf{E}>\mathrm{K}$ and $\mathrm{K}$ is the amount of equality before market intervention. The cases where utility is maximized when $\mathrm{E}=\mathrm{K}$ or remains constant when $1 \geq \mathrm{E} \geq \mathrm{K}$ are rejected because of a third assumption about the shape of the wealth-equality function at and near the point where there is no intervention. At the point of no intervention, $\frac{d W}{d E}=0$ and the rate at which intervention disrupts the system of production and causes a decrease in wealth will increase as the amount of intervention increases. On this basis, I will assume a smooth curve for $W=f(E)$, with the slope equaling 0 when $W$ is maximized at $E=K$; that is, $f^{\prime}(K)=\overline{0}$. Since total utility would increase as equality increases if it were not for the decreases in $W$, there will be values of $E$ where $W$ is decreasing but not decreasing at a rate sufficient to nullify the increase of $U$ caused by the redistribution (the increase in $E$ ). These values of $E$ will be when $E>K$. It should be noted that the amount a given transfer can be expected to increase utility, holding wealth constant, will vary inversely with equality-that is, the largest gains will be from the first transfers. (This fact, not relied upon below, strengthens the argument for some intervention.)

When $U$ increases more with a given change of $\mathrm{E}$ than it decreases with the corresponding change in $W, U$ is increasing. Assume $\frac{d W}{d E}$ to the derivative of $W=$ $f(E)$ and $\frac{\delta U}{\delta W}$ and $\frac{\delta U}{\delta e}$ are partial derivatives of $U=F(E, W)$. Since the directional derivative of $U$ along the curve of intersection of $W=f(E)$ and $U=F(E, W)$ (curve $\mathrm{C}$ ), is given by

$$
\mathrm{D}_{\mathrm{c}} \mathrm{U}=\frac{\delta \mathrm{U}}{\delta \mathrm{E}}+\frac{\delta \mathrm{U}}{\delta \mathrm{W}} \frac{\mathrm{dW}}{\mathrm{dE}}
$$

using $E$ as the curve parameter, $E$ increasing, and since $\frac{d W}{d E}=0$ when $E=K$, then $D_{c} U=\frac{\delta U}{\delta E}$ at the point on curve $C, P_{0}$, where $E=K$.

Since $\frac{\delta \mathrm{U}}{\delta \mathrm{E}}>0$ when $\mathrm{K} \leq \mathrm{E}<\mathrm{l}$ (because of the assumption of declining marginal utility of wealth) then $D_{c} U>0$ at $P_{o}$. Hence $U$ is increasing at that point. Therefore, $U$ will have a value larger than its value at $P_{0}$ at points on $C$ in the direction of increasing $\mathrm{E}$. Therefore, to maximize utility, given the assumptions above, we would have to increase equality to a point beyond that established by the perfect market. (I am indebted to Professor Budmon R. Davis who helped me with the mathematics of this article.) 
quently, at least a limited intervention to increase equality will always be justified under utilitarian principles. ${ }^{26}$

II

The foregoing reveals that setting a guaranteed minimum for individual income may be utilitarian even though it causes a reduction in total societal wealth. Beyond this, we need to know if there are situations in which we can justify social choices which would reduce the sum of individual utilities. To explore this question, we need to expand our horizons beyond the utilitarian view developed above, and we will do so by making use of a theory which Ronald Dworkin presented in lectures at Yale during the fall of $1970 .{ }^{27}$ We continue to accept the three assumptions made earlier.

Dworkin argues for the existence of rights. A right, in the sense Dworkin uses it, is a claim which the government would be wrong to override if the government's only grounds were that overriding the right would increase the well-being of the community as a whole. ${ }^{28}$ Thus, a right is a claim to have a certain need satisfied even if having this need satisfied causes a decrease in total or average utility. Rights are valid claims by individuals which limit the state's authority to apply strict utilitarian principles in its legislation and law. Dworkin therefore argues for minimum need satisfaction (i.e., recognition and fulfillment of rights) rather than a minimum income guarantee. ${ }^{20}$ Rights could be provided for by in-kind provision of needed goods or services, or by distributions of money based on an administrative determination of the amount required to satisfy just wants.

Dworkin argues that equal treatment under the law, freedom of speech, and, in some circumstances, the right to be left alone, are rights. ${ }^{30} \mathrm{He}$ also claims that his theory establishes a basis from which to argue that people have a right to have many of the goods which are supplied by the modern welfare state, such as education, fire protection, food, or medical care. The practical effect of satisfying just wants would be to increase the degree of economic equality, since the state

26. This is assuming perfect markets and no transaction costs. It is of course conceivable that administration costs of the intervention will cause a net loss of utility.

27. See note 5 supra.

28. Dworkin, supra note 5 , at 176-78.

29. Cf. Michelman, supra note 3 , at 9, 12-14. The words, "rights" and "just wants," can be seen as different labels for the same thing. If rights exist, they would perform the role of just wants in a minimum protection theory, such as that suggested by Michelman. I generally use the language of rights, rather than just wants, because by focusing on rights, the justification is clearer and identification is easier.

30. See Dworkin, supra note 5 , at 176-77. 
would be providing needed goods and services to those who could not otherwise afford them.

Dworkin's argument does not require that just wants invariably be satisfied. ${ }^{31}$ However, it does require that any abridgement of rights not be based solely on the utilitarian promotion of the general welfare. ${ }^{32}$ For example, a right could be limited or abridged if it conflicted with a competing right, but not because the cost of upholding the right was greater than the utilitarian benefit. ${ }^{33}$

What justification is there for recognizing the existence of rights as described above? From a utilitarian point of view, it may be necessary to leave some people in a condition where all their just wants are not satisfied. If we are to accept the theory of rights, then we must have some basis for rejecting the exclusive governance of utility. We may begin to establish this basis by considering the difference between being obliged and being obligated, ${ }^{34}$ for the practices constituting the realm of law in a society, or at least in Western liberal democratic societies, cannot be understood without the concept of obligation.

Stated briefly, being obliged has the connotation of being forced. For a person to be obliged, he must believe that his action was neces-

31. The use of "just want" as applied for education or food, for example, implies not only a "type" content but also a certain level of fulfillment. Education or caloric intake up to a certain quantitative and qualitative level may be considered a just want. Above those levels education or food may still be desired but it may no longer be a just want-the person may no longer have a right to demand a fulfillment of the desire, although he probably would have the freedom to purchase the goods necessary to match the desire. The term "just want," as used in this paper, refers to a right to goods fulfilling the want up to a certain justified level, not to any level the individual might desire.

32. Of course one might justify the protection of rights on the grounds that in the long run general welfare will be advanced by doing so. Dworkin admits that this sort of "institutional" utilitarianism is consistent with his theory. Dworkin, supra note 5 , at 186 n.l. See note 45 infra.

33. See Dworkin, supra note 5, at 188-92. In lectures at Yale, Dworkin argued that a version of utilitarianism may be an appropriate basis for legislation. He explained that utilitarianism derives from a larger moral construct which also justifies, in fact requires, limitations on the advancement of utility in certain circumstances. Consequently, the same framework may justify both utilitarianism and recognition of nonutilitarian rights.

34. Hart makes this distinction and it plays an important role in his theory of Iaw. See H.L.A. HART, ThE CONCEPT of LAw $79-88$ (1961). However, Hart does not adequately explain why a person ought to be obligated. He shows that Western legal practices require the existence of obligation but does not say what practices are required if obligation is to exist. A person is legally obligated, according to Hart, when his case falls under a rule identified by the fundamental rule of recognition which is not "valid" like other rules, but which is accepted. What Hart does not adequately do, and what Dworkin tries to do, is to explain how practices justify obligation-why a person ought to accept being obligated. In part, Hart fails to do this because his distinction between the internal and external aspect of rules suggests a normative acceptance of the sociologically vicwed rule. See Dworkin, Social Rules and Legal Theory, 81 YALE L.J. 855, 857-68 (1972). Dworkin argues that only existing social practices constitute the groundwork for the argument for particular rules-or for obligation. It is this argument which explains obligation and the rationale for rights. 
sary because of harm that would befall him if he did not so act. To be obligated means that one's case falls under a rule which for some reason one ought to obey, ${ }^{35}$ or that the case for being obligated in the particular situation is stronger than the case against it. ${ }^{36} \mathrm{H}$. L. A. Hart has argued that rules impose obligations "when the general demand for conformity is insistent and the social pressure brought to bear on those who deviate or threaten to deviate is great." 37 For a system of law to be efficacious, general acceptance of the obligatory nature of law may be necessary. Dworkin goes on to point out, however, that for a person to be obligated it is not necessary that he "feel" obligated or "feel" pressure or that he accept the obligation. No psychological factors are necessary, although they may commonly coexist with obligation. What is necessary is that good arguments can be made why a person ought to be obligated, why he ought to accept the duty or obey the law. ${ }^{38}$

Dworkin argues that Western social practices cannot be understood solely in terms of people's being obliged. Accurate understanding of such practices requires us to use the concept of obligation. ${ }^{39}$ To demonstrate this point, we shall explore two theories of society-the first based only on being obliged, the second involving obligation. The fit of the second with our practices amounts to an argument for the recognition of rights.

The first theory, which at various points resembles the model of Hobbes and of Locke, ${ }^{40}$ justifies the existence of a state (or sovereign) and of law as a response to the state of nature or the state of war, where no one is secure and everyone is free to use his power to take anything from anyone. ${ }^{41}$ In this situation, everyone would find it preferable to surrender his individual power to a sovereign who establishes order. The sovereign makes rules which are backed up by

35. See H.L.A. HART, supra note 34, at 83-88; cf. Dworkin, The Model of Rules, 35 U. CHr. L. REv. 14, 17 (1967).

36. Dworkin, supra note 35 , at 45 .

37. H.L.A. HART, supra note 34 , at 84 .

38. Hart and Dworkin part company at this point. Hart's solution-that a person is legally obligated when a rule of recognition is generally accepted and when the person's case falls under a rule which is valid because identified by the rule of recognition-is criticized by Dworkin.

39. See Dworkin, supra note 34 , at $877-78$.

40. T. Hobbes, Leviathan (M. Oakeshott ed. 1946); J. Locke, Two Treatises of GOVERNMENT (P. Laslett ed. 1965).

41. Whether the theorist thinks the concept of justice is applicable in the state of nature, or whether he thinks that in the state of nature a person ought to take only what he can use, is irrelevant for our purposes. Given that some want more than they have, and given no restraining influence, each person's desire for security, which is never achieved, requires that each person strive for more and more. Thus, the war of all against all results. 
his power, and people are obliged to obey, thus ensuring order, which is generally beneficial. Within this corporate framework, the only guide for the rule of the sovereign is the general good or the general welfare. Everyone is thought to be better off to the extent the corporate whole is better off, and the sovereign is the corporate management. Although this hypothetical may convince a person to give power over to the state so that order might be maintained, why would he be obligated, as opposed to obliged, to obey the law? Whenever he thinks his interests are better served by disobedience rather than obedience-because he thinks he will not be caught or because the punishment he will receive does not outweigh the advantage gained from disobedience-he has no reason to follow the rule. Thus, obligation is not established.

The second theory of society draws upon the thought of Rousseau and Kant. Dworkin argues that in this conception of society, a person must be asked, not told, to obey. Obligation can only be justified to the extent that an autonomous, free and equal person could rationally be expected to accept the request. A person can be forced to be obliged, but must consent to be obligated.

The request is made to him as a member of the political community. This concept of membership is in fact the grounding of obligation. Dworkin, following Rousseau, sees that obligation can exist among members of a community; it could not exist among units of a conglomerate. ${ }^{42}$ In the corporate model, maximizing was the only rational policy from the sovereign's or the subject's viewpoint. In the community or cooperative model, the state is required to give a justification for expecting each member to accept the rules of the community.

What is implied in asking a person to be a member of a community and to be obligated by its law? First, the potential member must be respected as a person, or else the request is more an order than an invitation. The request must be made to the person as an intelligent human being who is concerned with his humanity and is to some extent self-interested. To be obligated means that a person may be justifiably expected to obey even if disobedience would be to his individual advantage. To ask him thus to act to benefit others without regard for himself, he must be shown that others are asked to do the same. If not, the person in effect is asked to be a slave, not a member.

42. Rousseau, The Social Contract, in Social ContRAcr, at 175, 178-80 (E. Barker ed. 1962). 
As a prerequisite to asking him to accept obligation, then, he must be accorded respect as an autonomous person, equal to the respect he is asked to give others. Moreover, if the practices of the society indicate that certain things are necessary in order to be a full member, then the community must assure the provision of these things to all who are expected to be a part of the community. Anything less would not be a convincing basis from which to argue that he ought to join, that he ought to accept the request to be obligated.43 Or to put it in different terms, it would be an insult ${ }^{44}$ for a person to have to do without those things.

Simply stated, the justification for a person's being obligated requires the recognition of rights. We can ask a person to be obligated only if the legal order accords him respect as a free and equal person. For obligation to exist, rights must be granted. ${ }^{45}$ The content of the

43. In his article-Dworkin, supra note 5-Dworkin's approach was somewhat different than in his lectures. The elements are basically the same, however, although he arranged them differently. In the article, before tying the concept of rights to the discussion in the text above, he first shows that legal rights are only significant if they are rights against utility. He then demonstrates the existence of certain practices which indicate the existence of legal rights of this type. He writes:

Anyone who professes to take rights seriously ... must accept, at the minimum,

one or both of two important ideas. The first is the vague but powerful idea

of human dignity. This idea, associated with Kant, but defended by philosophers

of different schools, supposes that there are ways of treating a man that are in.

consistent with recognizing him as a full member of the human community. . .

The second is the more familiar idea of political equality.

Id. at $176,186.87$.

44. The use of the term "insult" here is not dependent on a particular person's feeling insulted. If, given the practices of that society, it would be degrading or disrespectful to a person's integrity or humanity to have to do without some goods or privileges, that is all that is required. It is not necessary for a person actually to feel insulted in order for him to have a right. On the other hand, if nobody in a society feels insulted when forced to do without certain goods, that fact would be strong evidence that the practices of that society do not justify the argument that those goods are within the ambit of rights or just wants. It might, however, be argued that a people's sensibilities were dulled, and therefore that certain unfelt deprivations might be deprivation of "rights."

45. Of course, one might try to argue that Dworkin is really a long-run utilitarian, i.e., that protection of rights is justified because in the long run such protection maximizes utility at the lowest cost. Dworkin argues that the scope of utilitarian governance be limited given the need to establish a basis for law, a basis which presupposes obligation and community. Law is necessary for the production of valued goods. To the extent that this reasoning is convincing, then perhaps utility itself requires limitations justified by rights even though rights limit immediate wealth maximization by the society. In other words, the costs of forcing people to be obliged (the only way to establish order if the system is unable to create a sense of obligation) may be higher than the expense involved in guaranteeing rights. Hence, guaranteeing rights would maximize utility; the rights approach would be utilitarian. Dworkin recognized this possibility, if one employs this peculiar form of institutional utilitarianism:

[One] may believe ... that the general good will be advanced, in the long run, only if we treat indignity or inequality as very great injustices, and never allow our opinions about the general good to justify them. I do not know of any good arguments for or against this sort of "institutional" utilitarianism, but it is consistent with my point, because it argues that we must treat violations of dignity 
rights depends on what is essential to being a fully respected, free and equal person in that community. ${ }^{46}$

There will always be arguments, based on a given culture's social practices, about when a person should be obligated and when he has a right which laws should not abridge. For example, one can justifiably ask a person to feel obligated by a law with which he disagrees by pointing out that a community cannot always reach unanimous agreement, and that the community cannot survive unless people respect the results of the decisionmaking process even when they dislike certain results. He is asked to respect a community of which he is a full member. On the other hand, to tell a particular person that he

and equality as special moral crimes, beyond the reach of ordinary utilitarian justification.

Dworkin, supra note 5 , at 186 n.l.

However, this form of utilitarianism departs strikingly from ordinary utilitarian justifications. Moreover, its foundation for rights is more tenuous than Dworkin's, because it depends on the contingent evaluation of long-term factors-on learning how obligated people feel when granted certain rights and how expensive obliging people to obey commands would be.

This long-run perspective also characterizes rule utilitarianism. As generally used, "rule utilitarianism" refers to positions which argue that utility is best maximized not by applying utilitarian analysis to the specific act in question but by following a rule of general application. These arguments are usually founded either on the existence of costs or difficulties in applying utility analysis to specific cases or on the utilitarian advantage of maintaining certain general practices. For a good philosophical treatment, see D. Lyons, Forms and Limits of Utilitarianism (1965) (especially at pp. VII-XI, 11, 119-60).

46. We may use Miranda v. Arizona, 384 U.S. 436 (1966), as a suggestive illustration. The majority in Miranda was concerned that legal rules not infringe upon rights which were basic to being a fully respected, free and equal member of the community. For example, the Court discusses how the interrogation atmosphere can be "destructive of human dignity." Id. at 457. And, "the constitutional foundation underlying the privilege is the respect a government-state or federal-must accord to the dignity and integrity of its citizens." Id. at 460 . The Court's concern for respecting the individual as a full member of the community-as a citizen-led it to reject "all interrogation practices which are likely to exert such pressure upon an individual as to disable him from making a free and rational choice." Id. at 464-65. The Miranda Court's usage of rights implies that the government must act in a way that respects the individual's full and equal membership in the community, that it must act in a way consistent with his dignity. The focus of the decision is therefore on the government's practices. This interpretation helps explain Miranda's requirement that warning be given irrespective of the detainee's age, education, intelligence, or his prior contact with authorities. Particularized need is irrelevant; all individuals are entitled to this treatment. Likewise, the question of knowing and intelligent waiver does not depend on the detainee's actual knowledge or the intelligence of the waiver of the individual's rights, but on the police using proper procedures, including procedures responsive to any observable indication of lack of voluntariness or knowledge. Id. at 479 .

Justice Harlan in dissent, joined by Justices White and Stewart, takes a different theoretical position. He employs utilitarian analysis to see if the practices are "worth the price paid for [them]." Id. at 516. Justice Harlan strongly condemns the majority for "passing over the costs and risks of its experiment." Id. at 517. However, not able or willing to make the required utilitarian calculations himself, he leaves them to the legislature. Id. at 524.

The majority, we may say, thus looked at what is required by a system of rights which respects a person's full and equal membership in the community, while the dissent feared the utilitarian consequences. The majority wrote from a Kantian perspective; the dissent adopted a Benthamite perspective. 
cannot speak out about matters that concern him deprives him of the preconditions for being human (as defined by our social practices) and thus shows a lack of respect for his full membership in the community. ${ }^{47}$ It would be telling him that his views about policy do not count like other views, that he is not a full member since he must give up more than others for the sake of the general good. ${ }^{48}$ This is more than asking him to follow a group decision which he does not like-it is asking him to deny his own integrity. ${ }^{49}$ The theory of obligation thus justifies the recognition of a "right" of free speech.

The content of all rights depends on the social practices of the specific community. In a society where education is generally available, where it is seen to be necessary for self-fulfillment and for successful economic activity, and where participants in the society's political and social culture are expected to be educated, the social practices in that society imply a right to education. In another community which believes that the ability to read the word of God is necessary for salvation and that salvation is the goal of human life, an individual could make a similar but more limited claim: that he has a right to be taught to read even if maximization of societal utility would not require it. Likewise, if a person was not considered respectable without possessing certain clothing, then access to clothing might be considered a right. It is not inconceivable that two different societies might establish drastically different sets of rights attaching to their respective members, for the specific content of rights depends on the actual social practices of the society, not on some unchanging transcendental conception of natural rights. It may nonetheless be the case that we find some particular rights, or the existence

47. See Rousseau, supra note 42 , at 191 n.1.

48. To require everyone not to speak or publicize opinions about a certain issue or policy is more complex. There are several approaches to such a prescription. In a way such a requirement shows disrespect for everybody. Or it might be said that Western practices require that those who are affected by rules or law must be allowed to participate in their formulation. Both of these arguments lead to a conclusion that everyone is suffering a loss of rights.

49. There might be a difference between requiring a person to do what he is conscientiously opposed to doing and prohibiting him from doing what he thinks should be permissible, or is in his self-interest to do. Several Supreme Court cases in the area of free exercise of religion suggest this distinction. Compare McGowan v. Maryland, 366 U.S. 420 (1961) (prohibiting someone from working on Sunday is constitutional), with Sherbert v. Verner, 374 U.S. 398 (1963) (requiring someone to work on Saturday is unconstitutional). It may also be a greater affront to a person's integrity to require him to act contrary to his values than to deny him the right to violate laws based on his judgments about the efficacy of underlying policies. If so, more deference ought to be given the draft resister who believes that war is unethical, than the doctor who believes socialized medicine is foolish. But these considerations are distinct from questions of rights. Rights do not depend on the actor's motives, but on arguments based on social practices. See Dworkin, supra note 5 , at 191 . 
of rights in general, required by social practices or forms of human interaction which are so basic a part of man's natural history, man's historically developed forms of life, that a society which did not have these practices would be unintelligible to us. ${ }^{50}$ If these deeply embedded practices justify individual rights, people would have a basis for objecting to any denial of these rights by existing institutions, but the grounds for criticism would not come from outside the human world, but would depend on actual practices of the society. ${ }^{61}$

If law only obliged people, the argument for rights would fail. But such a conception of law does not explain our social practices. Instead, modern social practices imply "obligation," which depends on the possibility of justifying to each member of the community the request that he obey the law. Obligation requires respect for the principles of community and individual integrity. The existence of obligation means rights must be recognized. Dworkin has provided an argument for the existence of rights in general and has shown how arguments for specific rights would be developed. And his argument shows why a limitation on the community's commitment to utilitarian maximization is required.

\section{III}

In the first section I attempted to show that some intervention to increase equality is justified by utilitarian analysis. The result would be to set a minimum income floor and to reduce somewhat the in-

50. See Rousseau, supra note 42 , at 170 . The institution of rights, I would argue, is part of the deep structure of our practices and is clearly required by the political and moral theory which interprets the meaning of our practices. The content of specific rights, however, is much more subject to changes in our forms of interaction and is more likely to differ in different countries and over time. And the degree of transitoriness of specific rights varies with the right in question; cf. L. WrTtcensteIn, ON CertainTy $\S \S 98.99$, at 15 (G. Anscombe \& G. von Wright eds. 1969):

98. . . Yet this is right: the same proposition may get treated at one time as something to test by experience, at another as a rule of testing.

99. And the bank of that river consists partly of hard rock, subject to no alteration or only to an imperceptible one, partly of sand, which now in one place now in another gets washed away, or deposited.

51. One criticism of Dworkin's conception of rights is that by rooting them within society, his thought seems conservatively biased. Several responses are available. First, the critic could be asked to show the validity of using a nonhistorical, nonsocial, Archimedian point from which to justify rights and make convincing moral argument; cf. L. WitTGENSTEIN, supra note $50, \$ 110$, at 17 . "As if giving grounds did not come to an end sometime. But the end is not an ungrounded presupposition: it is an ungrounded way of acting." Second, the criticism is misplaced. Dworkin's formulation is dynamic; for example, fundamental social practices may require that, in order to expect people to feel obligated, society guarantee to all members that which existing practices indicate is necessary for dignified human existence. This would be required even if implementation of the guarantee necessitates changes in specific social arrangements and recognition of previously unrecognized rights. 
comes of the richest. In the second section I described a theory of rights or just wants, and argued that a society like the United States must recognize some rights. I also noted that recognition of rights would have the effect of justifying intervention that increases equality. However, although both approaches justify intervention, taken alone $\mathrm{e}^{52}$ each approach would have a different effect on total utility. The different effect could arise either from requiring different amounts of redistribution or from different patterns of redistribution.53

Because of the differences in the underlying reasons for the redistribution under each approach, any equivalency in the amount of redistribution justified would be accidental. However, one could expect the amount of intervention and redistribution justified by the two approaches to be related. Under the utilitarian analysis presented above, the reason for setting a minimum income was that satisfaction of certain needs up to a certain level was important enough to people that they valued the first sum of money they received more highly than additional equivalent sums. In fact, it is quite likely that the basis of this valuation scheme-the reason why marginal utility of wealth declines-lies in people's perception that the first sums of money will allow them to fulfill their minimum needs, e.g., for medical care, food, and education. ${ }^{54}$ In any case, our earlier assumptions about utility functions suggest that a richer society would require a higher minimum income. In the Dworkin approach, the amount of intervention was determined by the amount that would be required to guarantee certain rights to everyone. Specific rights exist because social practices in that society indicate that a person must have these rights as a consequence of being a full and equal member of that community. As practices become more complex and involve people in greater and greater uses of wealth, that which will be necessary to be a full member will increase. In fact, aversion to certain consequences, the basis for the assumption of declining mar-

52. I will consider the two approaches alone rather than in combination in order to avoid confusion. The two are not inconsistent, and $I$ would argue that both approaches could be simultaneously adopted and applied. Dworkin argues that the legislature should promote utility except that it must guarantee rights. See Dworkin, supra note 5 , at $176-77$.

53. A different utility effect might result from the differences in reasons for the redistributions; $c f$. Tribe, Policy Science: Analysis or Ideology?, 2 PhiL. \& PuB. Affairs 65,87 n.54, 88-89 (1972); Dworkin, supra note 5, at 186 n.l.

54. Although this statement is generally true, it is not an attempt at psychological generalization. What people need is not always what they desire. Identification of basic needs is based on two kinds of facts: That the fulfillment of these needs in the given society 1 ) is generally thought desirable and 2) is generally viewed as providing necessary, though not sufficient, means for achieving the various goals of a person's life-e.g., happiness, success, glory. Given this method of identification, a close connection will exist between "basic needs" or "just wants" and what people in that society actually desire; $c f$. Michelman, supra note 3 , at 30 . 
ginal utility of wealth, is the subjective reflection of the argument based on social practices that certain rights must be respected if people are treated as full members of the community and can be expected to be obligated by the laws.

By assuming that the same amount would be redistributed under either approach, the utility effects of the different patterns of redistribution can be best observed. The utilitarian approach suggested setting a minimum income floor rather than giving the money available for redistribution to the specific individuals with the highest actual marginal utility for wealth. ${ }^{55}$ The minimum need fulfillment or rights approach does not require a specific minimum income. If a person has a right to medical care, free speech, education, or food, the claim is to have the "need" fulfilled up to a certain level. If a right to medical care exists, the sick person would have a claim to have more money spent on his medical needs than would the well person. Providing everyone a certain minimum amount would be irrelevant-the claimed right is to have enough goods or services to meet the need. ${ }^{50}$

The difference between the guaranteed minimum income approach and the minimum need fulfillment approach is obvious. If two individuals who have the same income are unable to satisfy a certain need, the cost of satisfying that particular need will depend upon the individual; however, the cost of raising each of their incomes to a minimum level is the same. The two approaches would lead to the same pattern of redistribution only if the cost of fulfilling each person's just wants was the same as the difference between his income (before redistribution) and the minimum income guaranteed by the utilitarian approach. ${ }^{57}$ Given differences between people, this simply would not happen. The amount of medical care needed to keep different people healthy varies; the cost of fire protection needed to give equal security to different individuals varies if only because of the location of their homes relative to the fire station; the costs of permitting two different people full freedom of speech varies. The costs of fulfilling just wants are certain to vary among people who have the same income.

\footnotetext{
55. See note 19 supra.

56. See note 31 supra.
57. If this were the case the only difference would be that in the case of rightssince the justification implies meeting a given need the state or the society might logically give inalienable vouchers for "goods" in kind (e.g., food stamps, a universal health insurance plan, the vote) rather than money. This procedure would not result in the same receipt of real income by the beneficiaries unless all recipients' value ranking of the fulfillment of every just want exceeded their value ranking for the expenditure of the same money on any other good which they were unable to purchase.
} 
In order to compare more fully the utility effects of the two approaches, we make two simplifying assumptions: 1) that the amount redistributed is the same under either approach; 2) that the people who receive distributions will be the same.58 Thus, in a society of population $\mathrm{P}$, a subset of the population, $\mathrm{S}$, will be below the minimum income level or will have claims that their just wants need satisfying. A given amount of money, $\mathbf{R}$, available for redistribution, will either raise $S$ to the minimum income level or fulfill the just wants of the members of $S$. To simplify further, assume that subset $S$ includes only two people-A with a present income of 3 and B with a present income of $\mathbf{3 - a n d}$ that the amount being redistributed, $R$, is 4. Assume A's right could be fulfilled with an expenditure of 1 and B's with an expenditure of 3. Then, under the minimum income or utility approach, $A$ and $B$ would both have 5 after the redistribution. Using the rights approach, $\mathrm{A}$ would have 4 and $\mathrm{B}$ would have 6. Using a typical utility function, for example, $u=\sqrt{w}, 60$ the total utility among subset $S$ would be $2 \sqrt{5}$ using the minimum income approach and $\sqrt{6}+\sqrt{4}$ using the rights approach. Since $2 \sqrt{5}>\sqrt{6}+\sqrt{4}$, the rights approach would result in less utility than the minimum income approach. ${ }^{60}$ In fact, any use of the amount redistributed other than to raise the minimum income results in a nonutilitarian solution. This result follows inevitably from the form of the equations, which reflect the standard utilitarian assumption that individuals on the average have the same utility for a certain amount of wealth. Thus, as long as the patterns of redistribution resulting from the two approaches differ, the rights approach, although it increases equality, does so on a nonutilitarian basis.

\section{Conclusion}

We have seen that both a utilitarian and a rights analysis justify market intervention by society, with the effect of increasing equality. Both reject maximization of wealth in favor of greater equality, but

58. We make the second assumption only for purposes of simplification; in actual practice it is quite likely that different subsets of the population would receive distributions under the two approaches. For example, a person who had above the guaranteed minimum income might have an unsatisfied right and require an expenditure. This assumption, like the first, only makes it easier to see the inherently different utility effects of the two approaches.

59. See pp. 46-48 supra.

60. This works out to be $4.47>4.45$. This result can be shown to be general. The claim is that $2 \sqrt{x}>\sqrt{x-1}+\sqrt{x+1}$ is always true. Since $2 \sqrt{x}>\sqrt{x-1}+\sqrt{x+1}$ can be simplified to $\frac{1}{x} 2>0$, which is universally true, the highest utility would invariably be achieved by equal distribution. 
they justify different redistributions. They would normally justify somewhat different amounts of redistribution, but even if the amount of redistribution justified turned out to be the same, the patterns of redistribution would diverge, yielding different effects on overall societal utility. Although not remaining strictly faithful to traditional utilitarianism, we could combine the two approaches. In fact, Dworkin has suggested that utilitarian principles ought normally to be the guide for legislative action, but that claims correctly based upon rights should take precedence over utilitarian considerations. The minimum income justified by utilitarianism should be provided. ${ }^{61}$ Beyond this point, if the rights approach is accepted as a proper limitation on the use of utilitarian precepts, the society should fulfill just wants. Even if the rights theory is accepted by the society, the utilitarian minimum income should still be provided because the commands of utilitarianism are to be obeyed where a right is not involved. ${ }^{62} \mathrm{~A}$ society could therefore provide both a minimum income and just wants satisfaction. The result might be that everyone is guaranteed, let us say, at least 5 (because that would maximize societal utilities $^{\text {b3 }}$ ), but some have a right to 6 or 7 (because the rights theory justifies fulfillment of their particularly costly just wants). Applied together, therefore, these two approaches could provide a better solution than either approach alone. ${ }^{64}$

61. It may be assumed that the rights-based distribution will decrease total societal utility below the point of optimum distribution of resources. The rights approach recognizes this decrease but argues that the importance of protecting rights outweighs utilitarian precepts. But even though the precepts are outweighed, they are not rendered utterly useless. Because we have accepted the assumption of declining individual marginal utility for wealth, some redistribution from those with a low marginal utility to those with a high (the poor) will be justified on utilitarian grounds even if there is a concurrent redistribution based on rights. A minimum income of some amount will generally increase societal utility over the utility supplied by the wealth-maximizing market distribution, even where the society concurrently make a rights-based distribution.

62. Dworkin himself has suggested that utilitarian principles ought normally to be the guide for legislative action, but that claims correctly based upon rights should take precedence over utilitarian considerations. Dworkin, supra note 5 .

63. Actually the income floor would be a little less than the 5 which utility justified without just want fulfillment. This result occurs because utility requires the last dollars taken from the top to give the same marginal utility as the last dollars redistributed to raise the income floor. Since rights have already taken the "cheapest" dollars (those giving rise to the fewest utils) from the top, the income floor would be requiring more expensive redistribution than justified; hence it must be lowered.

64. This theory may have certain practical implications. In practice, the legislature probably would make the utilitarian calculations that result in income floor maintenance, and could also make provision for just wants. The courts, which are ill equipped to make the utilitarian calculations, but are experienced in interpreting the meaning of our social practices and in analyzing arguments claiming the existence of, or justifying rights (courts are more experienced in hearing moral and legal arguments than in making empirical cost-benefit studies) could recognize and enforce rights or just want claims. 


\section{The Yale Law Journal}

Volume 84, Number 1, November 1974

David A. Martin

Editor-in-Chief

W. Duane Benton

Managing Editor

R. Hale Andrews, JR.

Philip C. Bobbitt

Laura J. Corwin

Alan B. Loughnan

Article \& Book Review Editors
MARK I. LEVY

Executive Editor

ANDREW H. CoHN

Note \& Project Editor

Holly E. Kendig

Charles H. Montange

STEPHEN R. MYSLIWIEC

LEWIS T. STEVENS

JOHN P. WHEELER III

Note Editors
Paul G. Abrams

Samuel A. Alito

NED T. AsHBY

RoY L. Brooks

SANFORd B. Ferguson

William A. Fietcher
ANTHONy T. KRONMAN

RICHARD B. LEVIN

WALTER P. LOUGHLIN

OWen E. MacBride

Elliot E. MaXwell

Charles A. Patrizia

Jan-Anders Paulsson
George K. RAHDERT JEFFrey L. SChuLte Mary A. Siegel Robert M. SMITH Michael L. Tabak EDWARd A. ZELINSKY

Secretaries to the Editors M. Olive Butrerfield, Pamela Willmotr

\section{Student Contributors to This Issue}

Walter P. Loughlin, Election Administration in New York City: Pruning the Political Thicket

Sanford B. Ferguson, Resale of Option Stock Acquired under Form S-8: $A$ Case for Expanding the Use of Rule 144

S. Wyatt McCallie, Business Necessity under Title VII of the Civil Rights Act of 1964: A No-Alternative Approach

Paul G. Abrams and Peter M. Hoffman, Common Law Rights for Private University Students: Beyond the State Action Principle 